\title{
Review \\ Therapeutic DNA Vaccines against HPV-Related Malignancies: Promising Leads from Clinical Trials
}

\author{
Jianming Tang ${ }^{1, *(1)}$, Mingzhu Li ${ }^{2}$, Chao Zhao ${ }^{2}$, Danhua Shen ${ }^{2}$, Lei Liu ${ }^{1}$, Xiujun Zhang ${ }^{1}$ and Lihui Wei ${ }^{2}(\mathbb{C}$ \\ 1 Aeonvital Biomedical Research Institute, Beijing 102208, China; leiliu@aeonvital.com (L.L.); \\ Azhang@aeonvital.com (X.Z.) \\ 2 Department of Gynecology and Obstetrics, Peking University People's Hospital, Beijing 100033, China; \\ mingzhu1815@163.com (M.L.); 0062034740@bjmu.edu.cn (C.Z.); shenpath59@163.com (D.S.); \\ weilhpku@163.com (L.W.) \\ * Correspondence: jamestang@aeonvital.com or jtang@uabmc.edu
}

check for updates

Citation: Tang, J.; Li, M.; Zhao, C.; Shen, D.; Liu, L.; Zhang, X.; Wei, L. Therapeutic DNA Vaccines against HPV-Related Malignancies: Promising Leads from Clinical Trials. Viruses 2022, 14, 239. https://doi.org/ $10.3390 / \mathrm{v} 14020239$

Academic Editor: Elizabeth White

Received: 20 December 2021

Accepted: 22 January 2022

Published: 25 January 2022

Publisher's Note: MDPI stays neutral with regard to jurisdictional claims in published maps and institutional affiliations.

Copyright: (C) 2022 by the authors. Licensee MDPI, Basel, Switzerland. This article is an open access article distributed under the terms and conditions of the Creative Commons Attribution (CC BY) license (https:// creativecommons.org/licenses/by/ $4.0 /)$.

\begin{abstract}
In 2014 and 2021, two nucleic-acid vaccine candidates named MAV E2 and VGX-3100 completed phase III clinical trials in Mexico and U.S., respectively, for patients with human papillomavirus (HPV)-related, high-grade squamous intraepithelial lesions (HSIL). These well-tolerated but still unlicensed vaccines encode distinct HPV antigens (E2 versus E6+E7) to elicit cell-mediated immune responses; their clinical efficacy, as measured by HSIL regression or cure, was modest when compared with placebo or surgery (conization), but both proved highly effective in clearing HPV infection, which should help further optimize strategies for enhancing vaccine immunogenicity, toward an ultimate goal of preventing malignancies in millions of patients who are living with persistent, oncogenic HPV infection but are not expected to benefit from current, prophylactic vaccines. The major roadblocks to a highly efficacious and practical product remain challenging and can be classified into five categories: (i) getting the vaccines into the right cells for efficient expression and presentation of HPV antigens (fusion proteins or epitopes); (ii) having adequate coverage of oncogenic HPV types, beyond the current focus on HPV-16 and -18; (iii) directing immune protection to various epithelial niches, especially anogenital mucosa and upper aerodigestive tract where HPVtransformed cells wreak havoc; (iv) establishing the time window and vaccination regimen, including dosage, interval and even combination therapy, for achieving maximum efficacy; and (v) validating therapeutic efficacy in patients with poor prognosis because of advanced, recurrent or non-resectable malignancies. Overall, the room for improvements is still large enough that continuing efforts for research and development will very likely extend into the next decade.
\end{abstract}

Keywords: HPV; DNA vaccine; epitope; cervical cancer; squamous intraepithelial lesions

\section{Introduction: The Need for Developing Therapeutic, Anti-HPV Vaccines}

Persistent infection with oncogenic types of human papillomavirus (HPV), including HPV-16, -18, -31, -33, -45, -52, -58 and close to 20 others, predisposes patients to cervical, penile, vulvar, vaginal, anal, and oropharyngeal malignancies [1-9]. Globally, these HPVassociated malignancies account for $4.5 \%$ of all human cancers, with an estimated annual case burden between 500,000 and 600,000 since 2012 [2,10]. Cervical cancer is also the second most common malignancy in women and disproportionally affects developing countries [2,11-13]. Although two prophylactic vaccines, Gardasil (introduced in 2006) [14] and Cervarix (in use since 2009) [15], are highly effective in preventing new infections with oncogenic HPV-16 and -18, as well as low-risk HPV-6 and -11 , the anti-HPV immunity induced by these commercially available vaccines is driven by antigens (i.e., recombinant capsid proteins) [14-16] that are rarely present in HPV-transformed cells. Accordingly, millions of patients who are living with persistent, oncogenic HPV infection or HPVassociated malignancies are not expected to benefit from these existing products $[17,18]$. 
Instead, new, therapeutic anti-HPV vaccines must target other HPV proteins, especially E6 and E7 that are the primary oncogenic factors [19-22].

The roads to therapeutic, anti-HPV vaccines have seen a steady flow of traffic in the past two decades, as reflected by the large number of research articles directly related to this topic: a survey conducted in November 2021 revealed 73 PubMed papers in 1999-2004, 165 in 2005-2009, 120 in 2010-2014, and 228 in 2015-2021 (Figure 1). An initial screening of clinical trials registered at ClinicalTrials.gov yielded more than 130 entries related to therapeutic DNA vaccines (the apparent front runners).

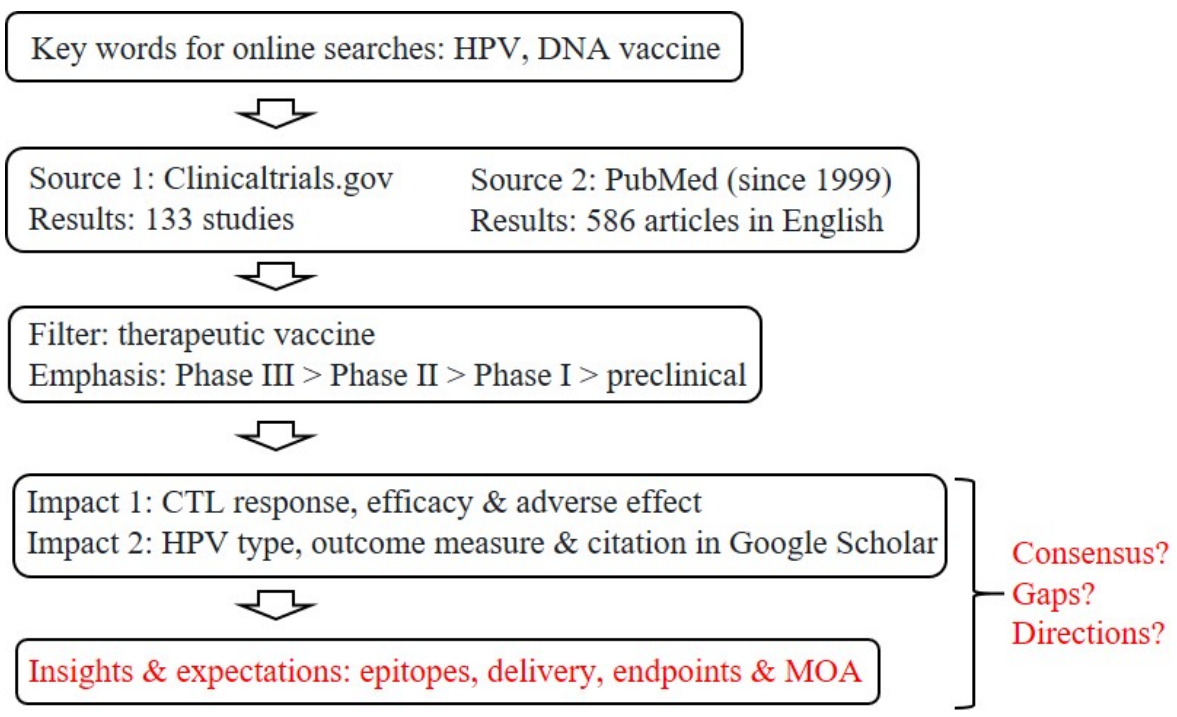

Figure 1. Strategies for screening and filtering current literature for a focused review. Given the large numbers of clinical trials and related literature, as already captured by two major public databases, our goal here is to summarize the current status of research and development toward therapeutic, anti-HPV DNA vaccines, with a focus on insights and expectations, as well as questions about potential consensus, remaining gaps and future directions for refinements or improvements. CTL, cytotoxic T-lymphocyte; MOA, mechanism of action.

Despite all the premises and advantages of research and development (R\&D) toward therapeutic, anti-HPV DNA vaccines (Figure 2), there are still no licensed products in the market, which raises three questions: (i) Is it possible to draw some consensus from past and ongoing efforts, especially clinical trials and high-impact studies? (ii) Are there gaps, roadblocks or bottlenecks that future R\&D must deal with? (iii) How is the current R\&D landscape likely to evolve, in terms of refinements and improvements? Our review will attempt to answer these lingering questions based on existing data in both academic and industrial arenas, with an emphasis on realistic deliverables and evidence from proof of concept research. Ramifications of the latest technological success in developing mRNAbased vaccines, which have a much shorter timeline than traditional pipelines, are also discussed to a limited extent. 


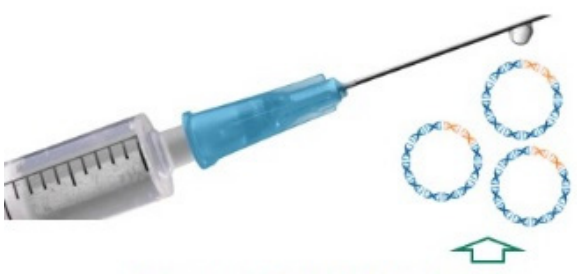

Therapeutic HPV DNA vaccine

Key features

- Pre-existing humoral immunity (HPVspecific antibody) does not interfere with the HPV DNA pay load

- Properly processed, intracellular HPV peptides (epitopes) induce CTLs

- Pre-existing memory CTLs (induced by natural infection) can be activated as well

- Anti-HPV CTLs find and eliminate HPV infected and/or -transformed cells

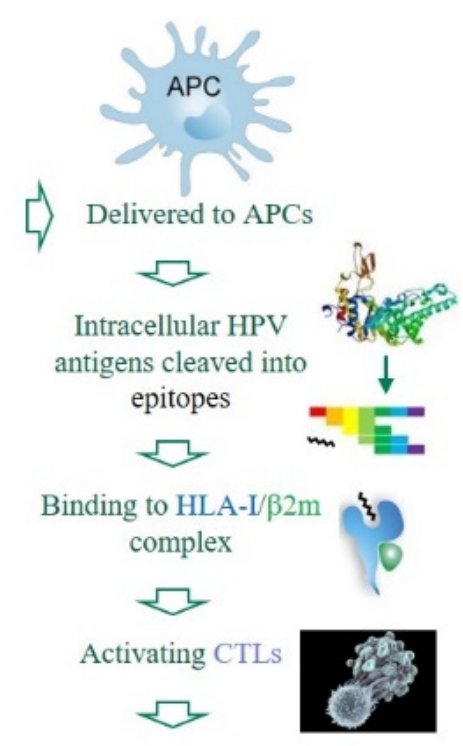

Locating \& killing HPV-infected cells

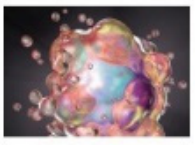

Tumor regression \& HPV clearance

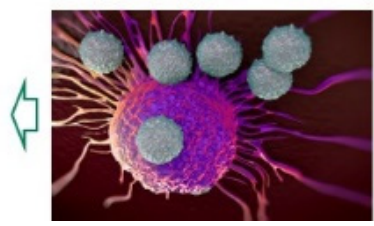

Figure 2. Premises and advantages of DNA-based, therapeutic anti-HPV vaccines. Unlike prophylactic HPV vaccines that induce HPV-specific antibodies to neutralize invading viruses, therapeutic DNA vaccines against HPV-induced malignancies must induce cytotoxic T-lymphocytes (CTLs) to eliminate HPV-infected or -transformed cells in patients with chronic/persistent infections [23,24]. Several critical components are color-coded. APCs, antigen-presenting cells; HLA-I, human leukocyte antigen class I (class I heavy chain); $\beta 2 \mathrm{~m}, \beta 2$ microglobulin (class I light chain).

\section{Key Advantages in Developing Therapeutic, Anti-HPV Vaccines}

DNA vaccines encoding tumor-specific antigens are highly attractive because of their ability to induce potent, cell-mediated immunity (as reviewed in refs. [25-29]). To develop therapeutic, anti-HPV vaccines, at least three major advantages are apparent. First, the HPV genome is relatively simple and small, with a circular, double-stranded DNA consisting of just nine open reading frames encoding seven early (E) proteins that govern viral replication and two late (L) proteins that form the viral capsid [6,8]. Since most $(\sim 90 \%)$ HPV infection leads to spontaneous clearance (self-cure) within two years, correlates of immune protection against these pathogens are readily defined. As such, there is a general consensus about the viral antigens and specific epitopes that should be targeted as the main immunogen in vaccine designs (Table 1). Second, a variety of clinically proven techniques, including regular Pap smears (for cervical cancer), tissue biopsies and analysis of HPV DNA, can routinely facilitate early diagnosis of HPV-associated malignancies [30-32]. Many patients with histologically confirmed, high-grade squamous intraepithelial lesion (HSIL, the equivalent of stage 2 and stage 3 cervical intraepithelial neoplasia, or CIN2/3), can be recruited for clinical trials without being confounded by other host factors, especially old age and compromised immune functions that a wide spectrum of aging-related cancers must confront. Indeed, most therapeutic HPV vaccines that have reached phase I clinical trials and beyond rely on HSIL regression and clearance of HPV DNA (instead of patient survival) as two key indicators of vaccine efficacy. Third, patients with persistent HPV infection and progress to malignancies are known to have immune memories against various HPV epitopes [33], some of which (e.g., E1, E2 and E5 epitopes) fall beyond E6 and E7 $[7,34]$ but can be harnessed for enhancing vaccine efficacy, either indirectly by 
serving as natural immune adjuvants (through cytokine induction) or directly by triggering anamnestic immune responses when these epitopes are added to the vaccine constructs.

Table 1. Oncogenic HPV-derived epitopes that are known to induce or enhance cytotoxic Tlymphocyte (CTL) responses in preclinical and clinical studies.

\begin{tabular}{|c|c|c|c|c|c|}
\hline Host & HPV Type & CTL Epitope & CTL Epitope Sequence & MHC Restriction & Reference(s) \\
\hline Mouse & HPV-16 & E6 (aa 48-57) & EVYDFAFRDL (EVL10) & $\mathrm{H}-2 \mathrm{~K}$ & PMC479075 [35] \\
\hline Mouse & HPV-16 & E7 (aa 49-57) & RAHYNIVTF (RAF9) & $\mathrm{H}-2 \mathrm{D}$ & PMID: 7,690,326 [36] \\
\hline Human & HPV-16 & E6 (aa 11-19) & KLPQLCTE $\underline{V}(\mathrm{KL9V})^{\mathrm{b}}$ & HLA-A*02 & PMC5444324 [37] \\
\hline Human & HPV-16 & E6 (aa 29-37) ${ }^{a}$ & TIHDIILEC (TIC9) & HLA-B*48 & PMC1182184 [38] \\
\hline Human & HPV-16 & E6 (aa 29-38) ${ }^{\text {a }}$ & TIHDIILECV (TIV10) & HLA-A*02 & PMC1797519 [39] \\
\hline Human & HPV-16 & E6 (aa 31-38) ${ }^{\mathrm{a}}$ & HDIILECV (HDV8) & HLA-B*40 & PMC1797519 [39] \\
\hline Human & HPV-16 & E6 (aa 52-61) & FAFRDLCIVY (FAY9) & HLA-B*35, -B*57 & $\begin{array}{l}\text { PMID: 15,358,648 [40], } \\
\text { PMC1182184 [38] }\end{array}$ \\
\hline Human & HPV-16 & E6 (aa 72-80) & KISEYRHYC (KIC9) & HLA-A*02 & PMC5444324 [37] \\
\hline Human & HPV-16 & E6 (aa 90-99) & QLYNKPLCD $\underline{V}$ (QLV10) ${ }^{b}$ & HLA-A*02 & PMC5444324 [37] \\
\hline Human & HPV-16 & E7 (aa 11-19) & YMLDLQPET (YMT9) & HLA-A*02 & PMC5444324 [37] \\
\hline Human & HPV-16 & E7 (aa 11-20) & YMLDLQPETT (YMT10) & HLA-A*02 & PMID: 7,538,538 [41] \\
\hline Human & HPV-16 & E7 (aa 7-15) & TLHEYMLDL (YLL9) & HLA-A*02, $-B^{*} 48$ & $\begin{array}{l}\text { PMID: 15,358,648 [40], } \\
\text { PMC5444324 [37] }\end{array}$ \\
\hline Human & HPV-16 & E7 (aa 61-69) & CDSTLRLCV (CDV9) & HLA-A*24 & PMID: 21,918,960 [42] \\
\hline Human & HPV-16 & E7 (aa 67-76) & LCVQSTHVDI (LCI10) & HLA-A*24 & PMID: 21,918,960 [42] \\
\hline Human & HPV-16 & E7 (aa 77-86) & RTLEDLLMG $\underline{V}$ (RTV10) $^{\mathrm{b}}$ & HLA-A*02 & PMC5444324 [37] \\
\hline Human & HPV-16 & E7 (aa 79-87) & LEDLLMGTL (LEL9) & HLA-B*60 & PMID: $15,358,648$ [40] \\
\hline Human & HPV-16 & E7 (aа 82-90) & LLMGTLGIV (LLV9) & HLA-A*02 & PMID: 7,538,538 [41] \\
\hline Human & HPV-16 & E7 (aa 86-93) & TLGIVCPI (TLI8) & HLA-A*02 & PMID: 7,538,538 [41] \\
\hline Human & HPV-18 & E6 (aa 13-21) & KLPDLCTEL (KLL9) & HLA-A*02 & PMID: 11,300,474 [43] \\
\hline Human & HPV-18 & E6 (aa 36-44) & KTVLELTEV (KTV9) & HLA-A*02 & PMID: $11,300,474$ [43] \\
\hline Human & HPV-18 & E6 (aa 50-58) & ELTEVFEFA (ELA9) & HLA-A*02 & PMID: $11,300,474$ [43] \\
\hline Human & HPV-18 & E6 (aa 54-62) & VVYRDSIPH (VVH9) & HLA-A*11 & PMID: $19,738,415$ [44] \\
\hline Human & HPV-18/45 & E6 (aa 67-75) & KCIDFYSRI (KCI9) & HLA-A*02 & PMID: 16,353,149 [40] \\
\hline Human & HPV-18 & E6 (aa 84-92) & SVYGDTLEK (SVK9) & HLA-A*11 & PMID: $19,738,415$ [44] \\
\hline Human & HPV-18 & E7 (aa 7-15) & TLQDIVLHL (TLL9) & HLA-A*02 & PMID: 11,300,474 [43] \\
\hline Human & HPV-18 & E7 (aa 81-95) & $\begin{array}{l}\text { DDLRAFQQLFLNTLS } \\
\text { (DDS15) }^{c}\end{array}$ & HLA-A*02, ${ }^{*} 11, * 24 \& 33$ & PMC4145224 [45] \\
\hline Human & HPV-18 & E7 (aa 86-94) & FQQLFLNTL (FQI9) & HLA-A*02 & PMID: $12,569,558$ [40] \\
\hline Human & HPV-18 & E7 (aa 88-97) & QLFLNTLSFV (QLV10) & HLA-A*02 & PMID: $11,426,965$ [46] \\
\hline Human & HPV-18 & E7 (aa 89-103) & $\begin{array}{l}\text { LFLNTLSFVCPWCAS } \\
\text { (LFS15) }^{\mathrm{C}}\end{array}$ & HLA-A*02, ${ }^{*} 11, * 24 \& 33$ & PMC4145224 [45] \\
\hline
\end{tabular}

${ }^{a}$ Substantial overlapping in these epitope sequences. ${ }^{b}$ Amino acid substitutions (bold and underlined) are introduced to enhance epitope affinity. ${ }^{c}$ Each of these 15 mer peptides contains multiple optimal epitopes. Abbreviations: aa, amino acid; HLA, human leukocyte antigen; MHC, major histocompatibility complex.

Additional advantages range from collaborative spirits to public interests. As HPVassociated conditions are at the intersection of infectious disease (immunology) and oncology, investigators with diverse expertise often join force to find ways to carry the field forward across regional and international boundaries [47-50]. Public interests in HPV- 
associated malignancies are also obvious because of their relevance to reproductive health. Indeed, a campaign launched by the World Health Organization in 2020 aimed to reduce global cervical cancer rate to less than 4 cases per 100,000 women-years through active vaccination, screening and treatment (a 90-70-90 goal) [51]. The current R\&D pipeline has further benefited from the availability of various resources, including in vitro systems for the propagation of infectious viruses (e.g., the HPV-18 organotypic cultures) [52] and preclinical models for testing vaccine efficacy against two major oncogenic subtypes (HPV-16 and -18) [36,53]. The widely used TC-1, a murine tumor cell line that expresses HPV-16 E6 and E7 (a key measure of authentication), facilitates direct comparison of research data from various laboratories.

\section{Factors That Hinder Efforts for Vaccine Development}

Oncogenic HPV is well-known for its ability to evade host immune responses [54-56], with three HPV proteins (E5, E6 and E7) interfering with both innate (e.g., interferon) immune pathways and the antigen-processing and -presenting machinery embedded in the major histocompatibility complex (MHC). These viral attributes impair immune surveillance by cytotoxic T-lymphocytes (CTLs) and may also vary by tissue compartments, as the polycistronic HPV gene expression patterns are often site-specific $[57,58]$ or depend on the stage of disease progression [57,59].

Poor immunogenicity of two major oncoproteins, E6 and E7, has also proved to be challenging [60]. To date, the number of known CTL epitopes defined in preclinical and clinical studies has remained small [36-41,43-46], and they tend to favor HPV-16 versus HPV-18 epitopes (Table 1). The list may change substantially if some of the predicted CTL epitopes [7,61-63] are validated experimentally, while epitopes beyond the E6 and E7 oncoproteins, including those in E5 [64-70], may help expand the spectrum of CTL targets as well [24].

The HLA class I (HLA-I) alleles known to recognize HPV CTL epitopes are also limited, with HLA-A*02 (mostly $A^{* 02: 01) ~ l e a d i n g ~ t h e ~ w a y ~(T a b l e ~ 1), ~ a n d ~ d a t a ~ a b o u t ~ o t h e r ~}$ HLA-I alleles are sparse. In silico studies using immunoinformatics tools have occasionally attempted to provide pertinent information about population coverage by potential epitopes [7,61-63], but regional and ethnic differences in the actual distribution of HLA-I alleles and supertypes [71,72] often obscure such efforts.

\section{Strategies for Enhancing Immunogenicity of Therapeutic DNA Vaccines}

Two common tactics - codon optimization in vaccine design and electroporation in vaccine delivery-seem to be effective in enhancing the immunogenicity of HPV E6- and E7-based DNA vaccines (Table 2), and the use of nanoplasmids to evade host intracellular defense has also gained some traction $[73,74]$. Other modifications have been shown to: (i) prevent extracellular DNA degradation (e.g., using a nano-carrier), (ii) guide plasmid DNA to professional antigen-presenting cells (APCs), including dendritic cells that can cross-present epitopes to both CD4 and CD8 T-cells [75]; (iii) co-deliver T-helper epitopes to tune up CTL functionality [76]; (iv) improve the efficiency of DNA transfection; (v) facilitate nuclear entry of plasmid DNA, (vi) minimize the interference of plasmid or vector backbones, and (vii) combine different immunomodulatory agents to achieve synergistic effects $[77,78]$. These alternative strategies, however, remain at the preclinical phase of evaluation. 
Table 2. Attributes of four therapeutic DNA vaccine candidates that have shown promising results against multiple HPV serotypes during or beyond phase I clinical trials.

\begin{tabular}{|c|c|c|c|c|}
\hline Attributes & \multicolumn{4}{|c|}{ Four Promising DNA Vaccine Candidates ${ }^{a}$ as of October 2021} \\
\hline Vaccine name & MVA E2 & VGX-3100 & GX-188E & pBI-11 \\
\hline Backbone & Vaccinia virus Ankara & $\begin{array}{c}\text { Two synthetic } \\
\text { plasmids/pVAX }\end{array}$ & Plasmid/pGX27 & pNGVL4a-Sig/E7(detox) \\
\hline Encoded antigen & $\begin{array}{c}\text { Cross-reactive E2 } \\
\text { (bovine papilloma virus) }\end{array}$ & E6 \& E7 (HPV-16 \& -18) & E6 \& E7 (HPV-16 \& -18) & E6 \& E7 (HPV-16 \& -18) \\
\hline Codon optimization & NA & Yes & Yes & Yes \\
\hline Other modification & NA & Domain deletions & NA & $\begin{array}{l}\text { Various mutations } \\
\text { (e.g., C24G \& E26G) }\end{array}$ \\
\hline Vaccine adjuvant & NA & NA & NA & $M t b$ HSP70 d \\
\hline Companion vaccine ${ }^{b}$ & NA & NA & NA & TA-HPV e (IM) \\
\hline Delivery & Injection, site-specific & IM, with electroporation & IM, with electroporation & $\mathrm{IM}$ \\
\hline Dosage & 6, weekly & 3 & 3 & 2 pBI-11 + 1 TA-HPV \\
\hline$N$ in phase I trial & 36 women [79] & 18 women [80] & 9 women [81] & 30 women ${ }^{f}$ [82] \\
\hline Phase I registration ID & Not applicable & NCT00685412 & NCT01634503 & NCT00788164 g \\
\hline Trial site(s) & Mexico & U.S. & South Korea & U.S. \\
\hline Target condition & CIN1-3 & CIN2/3 & CIN3 & CIN3 \\
\hline Trial end points & $\begin{array}{l}\text { CIN resolution } \\
\text { \& HPV clearance }\end{array}$ & $\begin{array}{l}\text { CIN regression } \\
\text { \& HPV clearance }\end{array}$ & $\begin{array}{l}\text { CIN regression } \\
\text { \& HPV clearance }\end{array}$ & $\begin{array}{l}\text { CIN regression } \\
\text { \& HPV clearance }\end{array}$ \\
\hline Phase III trial & $\begin{array}{l}\text { Yes, in } 1176 \text { women \& } \\
180 \text { men }^{\mathrm{c}}\end{array}$ & $\begin{array}{l}\text { Yes, in } 193 \text { subjects } \\
\text { (mITT) }\end{array}$ & NA & NA \\
\hline Latest report & PMC4270165 [83] & Website [84] & PMID: 31,727,676 [85] & $\begin{array}{c}\text { PMC7845631 [75] } \\
\text { and NCT00788164 g }\end{array}$ \\
\hline License & NA & NA & NA & NA \\
\hline & $\begin{array}{l}\text { a Three additional ther } \\
\text { I trial as well, as disce } \\
\text { control. d Heat shock } \\
\text { vaccinia virus express } \\
\text { into four treatment gr } \\
\text { intramuscular; mITT, } \\
\text { not applicable. }\end{array}$ & $\begin{array}{l}\text { peutic DNA vaccines against } \\
\text { sed in the text. }{ }^{b} \text { As used in } \\
\text { otein } 70 \text { helps direct vaccine } \\
\text { ng E6 and E7 for HPV-16 an } \\
\text { ups. g Ongoing until July } 202 \\
\text { rotocol-defined modified in }\end{array}$ & $\begin{array}{l}\mathrm{HPV}-16 \text { alone (mono-specific } \\
\text { arious combinations. }{ }^{\mathrm{c}} \mathrm{No} \\
\text { imunogen to dendritic cells [ } \\
-18 \text { [89], being tested in va } \\
\text { Abbreviations: CIN, cervic } \\
\text { ention to treat group; } M t b, \Lambda\end{array}$ & $\begin{array}{l}\text { [86-88] have reached phas } \\
\text { hdomization and no placeb } \\
\text { ]. }{ }^{\mathrm{e}} \text { TA-HPV is a recombinan } \\
\text { us treatment groups. }{ }^{\mathrm{f}} \text { Spli } \\
\text { intraepithelial neoplasia; IM } \\
\text { cobacterium tuberculosis; NA }\end{array}$ \\
\hline
\end{tabular}

To overcome limited choice of T-cell epitopes in the short E6 protein (158 amino acids) and E7 (105 amino acids), there is some success in the selective introduction of point mutations that enhance CTL responses [37]. In the case of HLA-A*02-restricted epitopes, KLV9 and RTV10 (Table 1) each has a single amino acid substitution beyond the anchoring positions. The induced CTL clones are expected to readily recognize the wild-type epitopes. The use of fusion proteins should also help expand the antigenic repertoire and boost vaccine immunogenicity $[24,60,86,90]$.

\section{Bottlenecks in Preclinical Systems}

As in other drug development, preclinical evaluations are essential to the elucidation of pharmacodynamics and pharmacokinetics, as well as toxicity/safety profiles. For the preclinical evaluation of anti-HPV vaccines, protective immunity is typically determined in mice engrafted with a murine tumor cell line, TC-1, which expresses HPV-16-specific E6 and E8 [53] or HPV-18 E6 after further modification [91]. Because MHC-TCR interaction is a prerequisite for T-cell activation, preclinical experiments must be done in C57BL/6 (B6) mice only [92]. Vaccines targeting other HPV antigens or E6 and E7 from non-HPV16/18 types must also come up with alternative preclinical systems, including different mouse strains. 


\section{Vaccine Candidates That Have Completed Phase III Clinical Trials}

Two promising DNA vaccine candidates against HSIL have gone through phase III clinical trials in Mexico and U.S., respectively (Figure 3). The first, MVA E2, was intended to induce cross-protective immunity using bovine papillomavirus (BHV)-specific E2 antigen inserted into a vaccinia virus (Table 2). Performances of MVA E2 at various developmental stages (over a 14-year period) are readily available in peer-reviewed publications [79,83,93-95]. The largest trial so far, as reported in 2014 [83], recruited 1356 patients (including 1176 women) who received six tissue-specific injections of $1 \times 10^{7}$ MVA E2 virus particles at weekly intervals. Overall, $1051(89 \%)$ women showed complete elimination of intraepithelial lesions after treatment, and $81 \%$ women cleared oncogenic HPV [83]. Among 180 men who received MVA E2, all cleared intraepithelial lesions [83]. However, in the absence of a control group for side-by-side comparison, the actual efficacy (and its confidence interval) of this vaccination protocol could not be established. An earlier phase II trial did reveal that 31 out of 34 HSIL women (91\%) who received MVA E2 either had total elimination of CIN $2 / 3$ or showed a $50 \%$ reduction in lesion sizes, with all vaccinated women having elevated CTLs and reduced HPV viral load. In comparison, $80 \%$ of women in the control (conization treatment, $n=20$ ) group had total elimination of CIN2/3 without clearing HPV [95]. The $11 \%$ difference between the two patient groups was marginal, although the viral load and CTL data in the vaccination group may eventually translate to improved long-term benefits (e.g., a potential reduction in CIN recurrence rate), as around $15 \%$ of patients with surgical procedures may have persistent/recurrent CIN in follow-up visits [96].

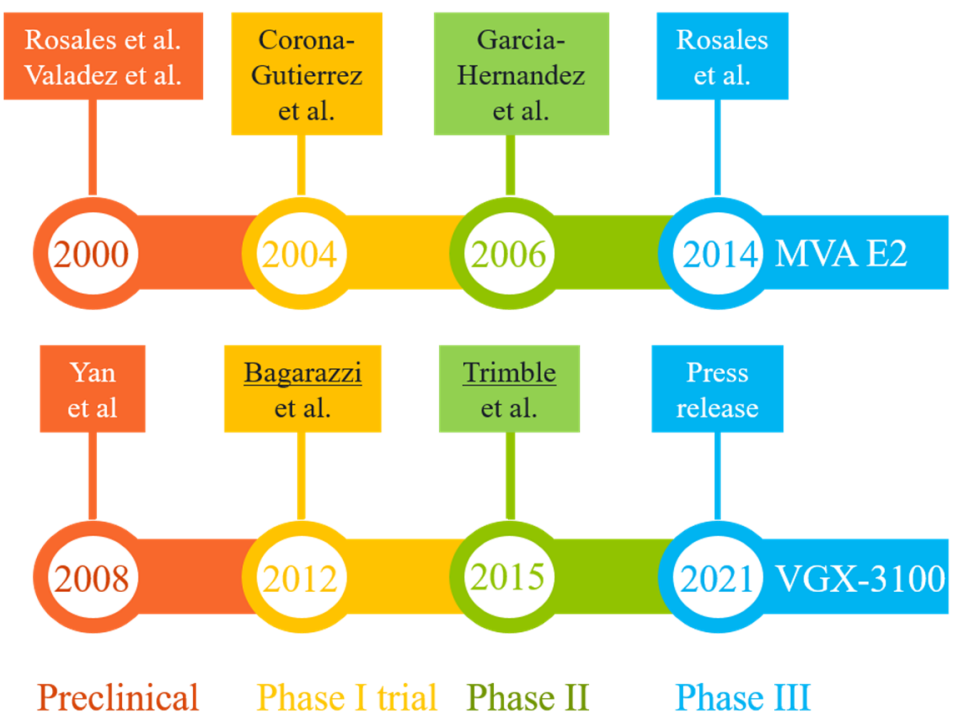

Figure 3. Milestones in the R\&D paths of two promising vaccine candidates (MVA E2 and VGX-3100) that have completed phase III clinical trials in patients with HPV-related pre-cancerous conditions (mostly high-grade squamous intraepithelial lesions). The results from key developmental stages are readily available in peer-reviewed publications $[79,80,83,93-95,97,98,100]$ or online resources [84,99]. The lead authors of two highly cited studies (more than 250 citations each) are underlined.

The second therapeutic candidate, VGX-3100, uses a mixture of two plasmids containing codon-optimized sequences corresponding to the E6 and E7 genes of HPV-16 and -18 (Table 2). The four developmental stages (preclinical and clinical evaluations) (Figure 3) lasted 13 years $[80,84,97-100]$. Data from the latest phase III trial (the REVEAL 1 Study), in the form of a press release in March 2021 [84], indicated that this vaccine met its primary endpoint in a modified intent-to-treat (mITT) analysis (i.e., excluding eight patients without sufficient results) - within the mITT subset $(N=193), 23.7 \%$ of 131 patients in the vaccinated group responded (with HSIL regression and HPV clearance), while $11.3 \%$ of 62 patients in the placebo group did so at week 36 . The rates of non-responders in both groups were 
quite high when compared with results for MVA E2 [83,95], but the modest vaccination efficacy (12.4\% difference, $95 \%$ confidence interval $=0.4 \%$ to $22.5 \%$ ) did exceed a statistical threshold ( $p=0.02)$. A concurrent phase III trial involving 198 participants (REVEAL 2) is expected to reach its primary endpoint in July 2022 [101]. Of note, the same vaccine has also shown promising phase II results in treating HPV-16/18-associated anal dysplasia [102] and vulvar dysplasia [103].

In terms of mechanism of action, the BPV E2 antigen encoded by MVA E2 is intended to induce immune responses that are cross-protective against HPV-a practice similar to the one used for the highly successful smallpox vaccine. A clear advantage with MVA E2 is the potential activation of tissue-resident T-cells around the HSIL sites (through repeated local injections). Although little is known about the repertoire of conserved CTL epitopes shared between BPV and HPV E2 proteins [104], a recent analysis of HPV-specific, tumor-inflitrating lymphocytes (TILs) from patients with head and neck cancer does reveal that E2, along with E5, can be prominent targets for therapeutic vaccines as both antigens are rich with experimentally verified CTL epitopes [34]. In contrast, VGX-3100 uses naked plasmids to deliver HPV E6 and E7 antigens that differ among HPV types, coupled with a proprietary delivery system for needle-free electroporation, a technique that is known to substantially enhance T-cell immunity [105-109]. The resulting effector T-cells, however, must travel a long way to reach their target cells before launching a strenuous battle in an unfriendly environment.

Adverse effects associated with site-specific injection of MVA E2 vaccine ranged from headache and transient fever to abdominal and joint pains that were observed at various frequencies $(6 \%$ to $69 \%$ ), all of which were considered mild (grade 1, no need for immediate intervention) $[83,95]$. For VGX-3100 that required IM injection and electroporation, the phase III trial did not identify serious adverse events related to treatment; mild to moderate adverse events were mostly self-resolving, as seen in earlier clinical trials [84].

Overall, MVA E2 and VGX-3100 differ so starkly in their design, delivery system, administration sites, dose schedules and efficacy (Table 2) that it is just impossible to draw a consensus conclusion about the right approach. The odds of getting both MVA E2 and VGX-3100 licensed for marketing are still low: the overall success rate from phase III to regulatory approval is around 50\%, with oncology products on the lower extreme $(<40 \%)[110,111]$.

\section{Promising Leads from Other Vaccine Candidates That Have Gone through Clinical Trials}

Two other DNA vaccines against multiple HPV types (HPV-16 and -18) have completed phase I trials in South Korea (NCT01634503) and U.S. (NCT00788164) (Table 2). The results for the GX-188E vaccine were reported in 2014 [81], while those for pBI-11 were announced seven years later [82]. Both showed positive results in terms of tolerance, CIN regression and HPV clearance, when delivered intramuscularly either alone or in modified protocols (e.g., in combination with a second vaccine). The multifaceted NCT00788164 trial is still ongoing until summer 2022.

Four additional DNA vaccine candidates target HPV-16 only (i.e., mono-specificity) in phase I or phase I/IIa trials, and their results were published between 2004 and 2021 [86-88,112,113]. Again, E6 and E7 antigens are the sole immunogens, and vaccines were delivered through intradermal or intramuscular injections, with the exception of a DNA tattoo vaccine [87]. Of note, two of these vaccines each has a built-in adjuvant: IL-2 in TG4001 [112] and MIP-1 $\alpha$ in VB10.16 [114]. A third candidate, AMV002 (formerly known as NTC-HPV16-E6/E7), involves partial codon optimization that retains portions of wild-type HPV sequences to ensure a simultaneous induction of innate immune responses [115]. The refinements provided by partial codon optimization are not trivial, as immune responses to cryptic epitopes introduced by codon optimization are known to divert T-cell responses away from the intended (authentic) epitopes [116]. 
Assuming that these candidates will successfully complete phase II and then advance to phase III trials, the timeline for completing these phases, as set by MVA E2 and VGX-3100 (Figure 3), ranges from six to eight years. Adding the extra time (about two years) required for collecting confirmatory data and securing regulatory approval, the best scenario is to see one of these existing candidates approved in 8-10 years. In other words, it may take another decade for these ongoing pipelines to deliver a final product.

\section{Directions for Further Refinements}

Therapeutic vaccine candidates that work well against HSIL (Table 2) may not live up to expectations for more advanced malignancies that are immunosuppressive and highly heterogeneous in nature $[27,117]$. In the worst scenario, several apparent bottlenecks (Table 3) may force new R\&D efforts back to square one: the selection of protective CTL epitopes that are endogenous in HPV-infected and -transformed cells. For example, a recent study provides convincing evidence that multiple CTL epitopes in HPV E5 may also serve as prominent targets for therapeutic vaccines [34].

Table 3. Summary of key points drawn from past and ongoing R\&D toward a DNA-based, anti-HPV vaccine.

\begin{tabular}{|c|c|c|}
\hline R\&D Staging & Bottleneck(s) & Directions for Improvement \\
\hline Vaccine design & $\begin{array}{l}\text { Limited choice of suitable } \\
\text { CTL epitopes }{ }^{\text {a }}\end{array}$ & Testing fusion proteins that expand the coverage of CTL epitopes \\
\hline Delivery & $\begin{array}{l}\text { Not always efficient, with } \\
\text { few adjuvants }\end{array}$ & Using LNP and nanoplasmids; directing APC-specific gene expression ${ }^{d}$ \\
\hline Preclinical system & $\begin{array}{c}\text { Poor coverage } \\
{\text { (mostly HPV-16-related })^{b}}^{b}\end{array}$ & $\begin{array}{l}\text { Rendering TC-1 to also express HPV-18-derived E6 and E7; developing } \\
\text { in vitro systems for rapid assessment of immunogenicity }\end{array}$ \\
\hline Clinical trials & $\begin{array}{l}\text { Limited efficacy data for } \\
\text { cancer patients }{ }^{c}\end{array}$ & $\begin{array}{l}\text { Comparing monotherapy versus combination therapy for late-stage patients } \\
\text { with poor prognosis }\end{array}$ \\
\hline & $\begin{array}{l}\text { a Especially in the two } \\
\text { HPV-18 (Table 1). }{ }^{c} \text { To } \\
\text { editing (CRISPR-Cas9) } \\
\text { in diameter) [119]. }\end{array}$ & $\begin{array}{l}\text { nain HPV oncoproteins, E6 and E7 (as shown in Table } 1) \cdot{ }^{\mathrm{b}} \text { Can be expanded to cor } \\
\text { te, most trials have involved precancer patients only (Table } 2) \cdot{ }^{\mathrm{d}} \text { As for cell-specific ge } \\
\text { 18]. Abbreviations: APC, antigen-presenting cell; LNP, lipid nanoparticle }(\sim 80-200 \mathrm{r}\end{array}$ \\
\hline
\end{tabular}

In the classic immunological toolbox, proper use of immune adjuvants improves the magnitude, breadth and durability of immune responses to protein-based vaccines [120], but the choice and formulation of adjuvants for enhancing CTL responses [121] or inducing polyfunctional CD4-cells to aid efficient and durable anti-tumor immunity [122] are not always clear. Activation of natural killer (NK) cells that prime dendritic cells toward a cross-talk with both CD4 and CD8 T-cells [123] is another worthy avenue, but reiterative assessment of these cellular mechanisms will undoubtedly further delay the R\&D progress.

A new frontline in cancer immunotherapy focuses on the direct modulation of the tumor microenvironment $[124,125]$. In particular, T-cell inhibitory receptors can be blocked by commercially available antibodies against several T-cell checkpoint inhibitors (e.g., PD-1 and PD-L1) [126-129]. Cultivation of TILs for adoptive cell therapy is another area of active research [130-132] that may eventually translate to combination therapy [133].

The success of new clinical trials may further depend on biomarkers of cancer invasiveness and prognosis, as patient enrollment and data analyses can be tweaked to maximize therapeutic outcomes [134-138]. Indeed, clinical trials using biomarkers for patient selection seem to have a much higher success rate than trials without biomarkers $[110,111]$.

\section{Ramifications of Recent Success in the Development of mRNA Vaccines}

The COVID-19 pandemic has brought a drastic change to the landscape of vaccine R\&D [139] after two preventive mRNA vaccines against SARS-CoV-2 infection beat all the DNA vaccines in receiving a green light first for emergency use authorization and then getting a formal approval by the US Food and Drug Administration for large scale use in adults 
and adolescents [140-142]. Early perceptions and concerns about acute and chronic adverse effects have been mostly dismissed [143-145], even for young children who are 5-11 years old [146]. The overwhelming and paradigm-shifting successes seen with mRNA vaccines in the Western world force all R\&D teams to at least reckon with the idea that existing mRNA vaccine platforms can be geared toward the rapid and cost-effective development of the next-generation therapeutic vaccines of medical and veterinary importance.

Much effort and many resources are being redirected to these new, spot-lighted avenues, but one must first and foremost recognize that access to mRNA vaccines is still limited to a handful of nations where logistics with mRNA vaccine manufacturing, transport and storage are well within their reaches. Unless mRNA vaccines and the nanotechnology (lipid nanoparticle) behind them $[119,147,148]$ can be reformulated to ensure mRNA integrity at ambient temperatures, preferably for weeks or even months, they are simply unpractical in resource-limiting communities. Thus, stable and cost-effective DNA vaccines that require less stringent conditions for the manufacturing process and also have a much longer shelf-life than mRNA vaccines still have important roles to play in the foreseeable future.

\section{Conclusions}

Following decades of heroic efforts, a steady progress in various R\&D pipelines for developing therapeutic DNA vaccines against HPV-associated malignancies still falls short of delivering a final (licensed) product to advance patient care. Two leading candidates have shown modest efficacy in late-stage clinical trials, but they share no further similarity to allow any other consensus, even about the very basics of target immunogens and delivery systems. The lessons learned from these and other candidate vaccines with clinical data, along with analyses of HPV-specific TILs, point to multiple gaps and bottlenecks that remain challenging. As such, the field may require rounds of reiterative evaluation of alternative strategies for optimal results.

Author Contributions: J.T., M.L., L.L. and X.Z. conducted literature search and compiled summary data. M.L., C.Z., D.S. and L.W. provided supporting materials from clinical laboratories. J.T. drafted the manuscript, while all authors read, edited or approved the version for publication. All authors have read and agreed to the published version of the manuscript.

Funding: This work did not receive external funding.

Institutional Review Board Statement: Not applicable.

Informed Consent Statement: Not applicable.

Data Availability Statement: The original data are derived from cited literature, which are available from PubMed and websites. The corresponding author does have a private collection (full text) of cited literature that can be shared if necessary.

Acknowledgments: We are grateful to Zhenguo Wen for valuable discussions about multiple topics covered by this article.

Conflicts of Interest: J.T., L.L. and X.Z. are employees of Aeonvital Biomedical Research Institute, with J.T. and X.Z. holding stakes in this private company. J.T. is also on the editorial board of Viruses. These affiliations, however, do not interfere with our ability to present unbiased information in this review article. No other financial interests can be construed as a potential conflict with this work.

\section{References}

1. Kreimer, A.R.; Clifford, G.M.; Boyle, P.; Franceschi, S. Human papillomavirus types in head and neck squamous cell carcinomas worldwide: A systematic review. Cancer Epidemiol. Biomark. Prev. 2005, 14, 467-475. [CrossRef]

2. Crow, J.M. HPV: The global burden. Nature 2012, 488, S2-S3. [CrossRef]

3. De Martel, C.; Ferlay, J.; Franceschi, S.; Vignat, J.; Bray, F.; Forman, D.; Plummer, M. Global burden of cancers attributable to infections in 2008: A review and synthetic analysis. Lancet Oncol. 2012, 13, 607-615. [CrossRef]

4. Doorbar, J.; Quint, W.; Banks, L.; Bravo, I.G.; Stoler, M.; Broker, T.R.; Stanley, M.A. The biology and life-cycle of human papillomaviruses. Vaccine 2012, 30, F55-F70. [CrossRef] 
5. Forman, D.; de Martel, C.; Lacey, C.J.; Soerjomataram, I.; Lortet-Tieulent, J.; Bruni, L.; Vignat, J.; Ferlay, J.; Bray, F.; Plummer, M.; et al. Global burden of human papillomavirus and related diseases. Vaccine 2012, 30, F12-F23. [CrossRef]

6. Boda, D.; Docea, A.O.; Calina, D.; Ilie, M.A.; Caruntu, C.; Zurac, S.; Neagu, M.; Constantin, C.; Branisteanu, D.E.; Voiculescu, V.; et al. Human papilloma virus: Apprehending the link with carcinogenesis and unveiling new research avenues (Review). Int. J. Oncol. 2018, 52, 637-655. [CrossRef]

7. Kaliamurthi, S.; Selvaraj, G.; Kaushik, A.C.; Gu, K.R.; Wei, D.Q. Designing of CD8 ${ }^{+}$and CD8 ${ }^{+}$-overlapped CD4 ${ }^{+}$epitope vaccine by targeting late and early proteins of human papillomavirus. Biologics 2018, 12, 107-125.

8. Syrjanen, S. Oral manifestations of human papillomavirus infections. Eur. J. Oral Sci. 2018, 126, 49-66. [CrossRef]

9. Centers for Disease Congtrol and Prevention (CDC) Cancers Caused by HPV. Available online: https://www.cdc.gov/hpv/ parents / cancer.html (accessed on 28 October 2021).

10. Smalley Rumfield, C.; Roller, N.; Pellom, S.T.; Schlom, J.; Jochems, C. Therapeutic Vaccines for HPV-Associated Malignancies. Immunotargets Ther. 2020, 9, 167-200. [CrossRef]

11. Agosti, J.M.; Goldie, S.J. Introducing HPV vaccine in developing countries-Key challenges and issues. N. Engl. J. Med. 2007, 356, 1908-1910. [CrossRef]

12. Bharadwaj, M.; Hussain, S.; Nasare, V.; Das, B.C. HPV \& HPV vaccination: Issues in developing countries. Indian J. Med. Res. $2009,130,327-333$.

13. Soerjomataram, I.; Lortet-Tieulent, J.; Parkin, D.M.; Ferlay, J.; Mathers, C.; Forman, D.; Bray, F. Global burden of cancer in 2008: A systematic analysis of disability-adjusted life-years in 12 world regions. Lancet 2012, 380, 1840-1850. [CrossRef]

14. Shi, L.; Sings, H.L.; Bryan, J.T.; Wang, B.; Wang, Y.; Mach, H.; Kosinski, M.; Washabaugh, M.W.; Sitrin, R.; Barr, E. GARDASIL: Prophylactic human papillomavirus vaccine development-From bench top to bed-side. Clin. Pharmacol. Ther. 2007, 81, 259-264. [CrossRef] [PubMed]

15. Deschuyteneer, M.; Elouahabi, A.; Plainchamp, D.; Plisnier, M.; Soete, D.; Corazza, Y.; Lockman, L.; Giannini, S.; Deschamps, M. Molecular and structural characterization of the L1 virus-like particles that are used as vaccine antigens in Cervarix, the AS04-adjuvanted HPV-16 and -18 cervical cancer vaccine. Hum. Vaccines 2010, 6, 407-419. [CrossRef] [PubMed]

16. Einstein, M.H.; Baron, M.; Levin, M.J.; Chatterjee, A.; Edwards, R.P.; Zepp, F.; Carletti, I.; Dessy, F.J.; Trofa, A.F.; Schuind, A.; et al. Comparison of the immunogenicity and safety of Cervarix and Gardasil human papillomavirus (HPV) cervical cancer vaccines in healthy women aged 18-45 years. Hum. Vaccines 2009, 5, 705-719. [CrossRef] [PubMed]

17. Athanasiou, A.; Bowden, S.; Paraskevaidi, M.; Fotopoulou, C.; Martin-Hirsch, P.; Paraskevaidis, E.; Kyrgiou, M. HPV vaccination and cancer prevention. Best Pract. Res. Clin. Obstet. Gynaecol. 2020, 65, 109-124. [CrossRef] [PubMed]

18. Hildesheim, A.; Gonzalez, P.; Kreimer, A.R.; Wacholder, S.; Schussler, J.; Rodriguez, A.C.; Porras, C.; Schiffman, M.; Sidawy, M.; Schiller, J.T.; et al. Impact of human papillomavirus (HPV) 16 and 18 vaccination on prevalent infections and rates of cervical lesions after excisional treatment. Am. J. Obstet. Gynecol. 2016, 215, 212.e1-212.e15. [CrossRef]

19. Munger, K.; Scheffner, M.; Huibregtse, J.M.; Howley, P.M. Interactions of HPV E6 and E7 oncoproteins with tumour suppressor gene products. Cancer Surv. 1992, 12, 197-217.

20. Yim, E.K.; Park, J.S. The role of HPV E6 and E7 oncoproteins in HPV-associated cervical carcinogenesis. Cancer Res. Treat. 2005, 37, 319-324. [CrossRef]

21. Ghittoni, R.; Accardi, R.; Hasan, U.; Gheit, T.; Sylla, B.; Tommasino, M. The biological properties of E6 and E7 oncoproteins from human papillomaviruses. Virus Genes 2010, 40,1-13. [CrossRef]

22. Bava, S.V.; Thulasidasan, A.K.; Sreekanth, C.N.; Anto, R.J. Cervical cancer: A comprehensive approach towards extermination Ann. Med. 2016, 48, 149-161. [CrossRef] [PubMed]

23. Lin, K.; Roosinovich, E.; Ma, B.; Hung, C.F.; Wu, T.C. Therapeutic HPV DNA vaccines. Immunol. Res. 2010, 47, 86-112. [CrossRef] [PubMed]

24. Boilesen, D.R.; Nielsen, K.N.; Holst, P.J. Novel Antigenic Targets of HPV Therapeutic Vaccines. Vaccines 2021, 9, 1262. [CrossRef]

25. Coban, C.; Koyama, S.; Takeshita, F.; Akira, S.; Ishii, K.J. Molecular and cellular mechanisms of DNA vaccines. Hum. Vaccines 2008, 4, 453-456. [CrossRef]

26. Moss, R.B. Prospects for control of emerging infectious diseases with plasmid DNA vaccines. J. Immune Based Ther. Vaccines 2009, 7, 3. [CrossRef]

27. Jahanafrooz, Z.; Baradaran, B.; Mosafer, J.; Hashemzaei, M.; Rezaei, T.; Mokhtarzadeh, A.; Hamblin, M.R. Comparison of DNA and Mrna vaccines against cancer. Drug Discov. Today 2020, 25, 552-560. [CrossRef]

28. Qin, F.; Xia, F.; Chen, H.; Cui, B.; Feng, Y.; Zhang, P.; Chen, J.; Luo, M. A Guide to Nucleic Acid Vaccines in the Prevention and Treatment of Infectious Diseases and Cancers: From Basic Principles to Current Applications. Front. Cell Dev. Biol. 2021, 9, 633776. [CrossRef] [PubMed]

29. Saxena, M.; van der Burg, S.H.; Melief, C.J.M.; Bhardwaj, N. Therapeutic cancer vaccines. Nat. Rev. Cancer 2021, 21, 360-378. [CrossRef]

30. Mathur, S.P.; Mathur, R.S.; Creasman, W.T.; Underwood, P.B.; Kohler, M. Early non-invasive diagnosis of cervical cancer: Beyond Pap smears and human papilloma virus (HPV) testing. Cancer Biomark. 2005, 1, 183-191. [CrossRef]

31. Chera, B.S.; Kumar, S.; Beaty, B.T.; Marron, D.; Jefferys, S.; Green, R.; Goldman, E.C.; Amdur, R.; Sheets, N.; Dagan, R.; et al. Rapid Clearance Profile of Plasma Circulating Tumor HPV Type 16 DNA during Chemoradiotherapy Correlates with Disease Control in HPV-Associated Oropharyngeal Cancer. Clin. Cancer Res. 2019, 25, 4682-4690. [CrossRef] 
32. Mahmoodi, P.; Rezayi, M.; Rasouli, E.; Avan, A.; Gholami, M.; Mobarhan, M.G.; Karimi, E.; Alias, Y. Early-stage cervical cancer diagnosis based on an ultra-sensitive electrochemical DNA nanobiosensor for HPV-18 detection in real samples. J. Nanobiotechnol. 2020, 18, 11. [CrossRef] [PubMed]

33. Bhatt, K.H.; Neller, M.A.; Srihari, S.; Crooks, P.; Lekieffre, L.; Aftab, B.T.; Liu, H.; Smith, C.; Kenny, L.; Porceddu, S.; et al. Profiling HPV-16-specific T cell responses reveals broad antigen reactivities in oropharyngeal cancer patients. J. Exp. Med. 2020, 217, e20200389. [CrossRef] [PubMed]

34. Eberhardt, C.S.; Kissick, H.T.; Patel, M.R.; Cardenas, M.A.; Prokhnevska, N.; Obeng, R.C.; Nasti, T.H.; Griffith, C.C.; Im, S.J.; Wang, X.; et al. Functional HPV-specific PD-1+ ${ }^{+}$stem-like CD8 T cells in head and neck cancer. Nature 2021, 597, 279-284. [CrossRef] [PubMed]

35. Peng, S.; Ji, H.; Trimble, C.; He, L.; Tsai, Y.C.; Yeatermeyer, J.; Boyd, D.A.; Hung, C.F.; Wu, T.C. Development of a DNA vaccine targeting human papillomavirus type 16 oncoprotein E6. J. Virol. 2004, 78, 8468-8476. [CrossRef] [PubMed]

36. Feltkamp, M.C.; Smits, H.L.; Vierboom, M.P.; Minnaar, R.P.; de Jongh, B.M.; Drijfhout, J.W.; ter Schegget, J.; Melief, C.J.; Kast, W.M. Vaccination with cytotoxic T lymphocyte epitope-containing peptide protects against a tumor induced by human papillomavirus type 16-transformed cells. Eur. J. Immunol. 1993, 23, 2242-2249. [CrossRef]

37. Tsang, K.Y.; Fantini, M.; Fernando, R.I.; Palena, C.; David, J.M.; Hodge, J.W.; Gabitzsch, E.S.; Jones, F.R.; Schlom, J. Identification and characterization of enhancer agonist human cytotoxic T-cell epitopes of the human papillomavirus type 16 (HPV16) E6/E7. Vaccine 2017, 35, 2605-2611. [CrossRef]

38. Nakagawa, M.; Kim, K.H.; Moscicki, A.B. Patterns of CD8 T-cell epitopes within the human papillomavirus type 16 (HPV 16) E6 protein among young women whose HPV 16 infection has become undetectable. Clin. Diagn. Lab. Immunol. 2005, 12, 1003-1005. [CrossRef]

39. Nakagawa, M.; Kim, K.H.; Gillam, T.M.; Moscicki, A.B. HLA class I binding promiscuity of the CD8 T-cell epitopes of human papillomavirus type 16 E6 protein. J. Virol. 2007, 81, 1412-1423. [CrossRef]

40. Nakagawa, M.; Kim, K.H.; Moscicki, A.B. Different methods of identifying new antigenic epitopes of human papillomavirus type 16 E6 and E7 proteins. Clin. Diagn. Lab. Immunol. 2004, 11, 889-896. [CrossRef]

41. Ressing, M.E.; Sette, A.; Brandt, R.M.; Ruppert, J.; Wentworth, P.A.; Hartman, M.; Oseroff, C.; Grey, H.M.; Melief, C.J.; Kast, W.M. Human CTL epitopes encoded by human papillomavirus type 16 E6 and E7 identified through in vivo and in vitro immunogenicity studies of HLA-A*0201-binding peptides. J. Immunol. 1995, 154, 5934-5943.

42. Jang, S.; Kim, Y.T.; Chung, H.W.; Lee, K.R.; Lim, J.B.; Lee, K. Identification of novel immunogenic human leukocyte antigen-A 2402-binding epitopes of human papillomavirus type 16 E7 for immunotherapy against human cervical cancer. Cancer 2012, 118, 2173-2183. [CrossRef]

43. Rudolf, M.P.; Man, S.; Melief, C.J.; Sette, A.; Kast, W.M. Human T-cell responses to HLA-A-restricted high binding affinity peptides of human papillomavirus type 18 proteins E6 and E7. Clin. Cancer Res. 2001, 7, 788s-795s. [PubMed]

44. Chen, H.W.; Leng, C.H.; Liu, H.Y.; Cheng, W.F.; Chang, Y.W.; Wu, P.Y.; Lien, S.P.; Huang, T.Y.; Chiang, S.K.; Lin, M.H.; et al. Identification of HLA-A11-restricted CTL epitopes derived from HPV type 18 using DNA immunization. Cancer Biol. Ther. 2009, 8, 2025-2032. [CrossRef] [PubMed]

45. Kim, S.; Chung, H.W.; Lee, K.R.; Lim, J.B. Identification of novel epitopes from human papillomavirus type 18 E7 that can sensitize PBMCs of multiple HLA class I against human cervical cancer. J. Transl. Med. 2014, 12, 229. [CrossRef] [PubMed]

46. Castellanos, M.R.; Hayes, R.L.; Maiman, M.A. Synthetic peptides induce a cytotoxic response against human papillomavirus type-18. Gynecol. Oncol. 2001, 82,77-83. [CrossRef]

47. Ferguson, M.; Wilkinson, D.E.; Zhou, T. WHO meeting on the standardization of HPV assays and the role of the WHO HPV Laboratory Network in supporting vaccine introduction held on 24-25 January 2008, Geneva, Switzerland. Vaccine 2009, 27, 337-347. [CrossRef]

48. Adebamowo, S.N.; Dareng, E.O.; Famooto, A.O.; Offiong, R.; Olaniyan, O.; Obende, K.; Adebayo, A.; Ologun, S.; Alabi, B.; Achara, P.; et al. Cohort Profile: African Collaborative Center for Microbiome and Genomics Research's (ACCME's) Human Papillomavirus (HPV) and Cervical Cancer Study. Int. J. Epidemiol. 2017, 46, 1745a-1745j. [CrossRef]

49. Wallace-Brodeur, R.; Li, R.; Davis, W.; Humiston, S.; Albertin, C.; Szilagyi, P.G.; Rand, C.M. A quality improvement collaborative to increase human papillomavirus vaccination rates in local health department clinics. Prev. Med. 2020, 139, 106235. [CrossRef]

50. Song, F.; Du, H.; Wang, C.; Huang, X.; Qu, X.; Wei, L.; Belinson, J.L.; Wu, R.; The Chinese Multi-site Screening Trial (CHIMUST) Team. The effectiveness of human papillomavirus load, reflected by cycle threshold values, for the triage of HPV-positive self-samples in cervical cancer screening. J. Med. Screen. 2021, 28, 318-324. [CrossRef]

51. World Health Organization (WHO). Global Strategy to Accelerate the Elimination of Cervical Cancer as a Public Health Problem Available online: https://www.who.int/publications/i/item/9789240014107 (accessed on 17 November 2021).

52. Wang, H.K.; Broker, T.R.; Chow, L.T. Robust HPV-18 production in organotypic cultures of primary human keratinocytes. Methods Mol. Biol. 2015, 1249, 93-109.

53. Lin, K.Y.; Guarnieri, F.G.; Staveley-O'Carroll, K.F.; Levitsky, H.I.; August, J.T.; Pardoll, D.M.; Wu, T.C. Treatment of established tumors with a novel vaccine that enhances major histocompatibility class II presentation of tumor antigen. Cancer Res. 1996, 56, 21-26. [PubMed] 
54. Evans, M.; Borysiewicz, L.K.; Evans, A.S.; Rowe, M.; Jones, M.; Gileadi, U.; Cerundolo, V.; Man, S. Antigen processing defects in cervical carcinomas limit the presentation of a CTL epitope from human papillomavirus 16 E6. J. Immunol. 2001, 167, 5420-5428. [CrossRef] [PubMed]

55. Steinbach, A.; Riemer, A.B. Immune evasion mechanisms of human papillomavirus: An update. Int. J. Cancer 2018, 142, 224-229. [CrossRef] [PubMed]

56. Zhou, C.; Tuong, Z.K.; Frazer, I.H. Papillomavirus Immune Evasion Strategies Target the Infected Cell and the Local Immune System. Front. Oncol. 2019, 9, 682. [CrossRef] [PubMed]

57. Graham, S.V. Human papillomavirus: Gene expression, regulation and prospects for novel diagnostic methods and antiviral therapies. Future Microbiol. 2010, 5, 1493-1506. [CrossRef] [PubMed]

58. Egawa, N.; Egawa, K.; Griffin, H.; Doorbar, J. Human Papillomaviruses; Epithelial Tropisms, and the Development of Neoplasia. Viruses 2015, 7, 3863-3890. [CrossRef]

59. Groves, I.J.; Coleman, N. Pathogenesis of human papillomavirus-associated mucosal disease. J. Pathol. 2015, 235, 527-538 [CrossRef]

60. Martinez-Perez, A.G.; Perez-Trujillo, J.J.; Garza-Morales, R.; Ramirez-Avila, N.E.; Loera-Arias, M.J.; Gomez-Gutierrez, J.G.; Saucedo-Cardenas, O.; Garcia-Garcia, A.; Rodriguez-Rocha, H.; Montes-de-Oca-Luna, R. An Oncolytic Adenovirus Encoding SA-4-1BBL Adjuvant Fused to HPV-16 E7 Antigen Produces a Specific Antitumor Effect in a Cancer Mouse Model. Vaccines 2021, 9, 149. [CrossRef]

61. Kayyal, M.; Bolhassani, A.; Noormohammadi, Z.; Sadeghizadeh, M. In Silico Design and Immunological Studies of Two Novel Multiepitope DNA-Based Vaccine Candidates Against High-Risk Human Papillomaviruses. Mol. Biotechnol. 2021, 63, 1192-1222. [CrossRef]

62. Panahi, H.A.; Bolhassani, A.; Javadi, G.; Noormohammadi, Z. A comprehensive in silico analysis for identification of therapeutic epitopes in HPV16, 18, 31 and 45 oncoproteins. PLoS ONE 2018, 13, e205933. [CrossRef]

63. Namvar, A.; Panahi, H.A.; Agi, E.; Bolhassani, A. Development of HPV16,18,31,45 E5 and E7 peptides-based vaccines predicted by immunoinformatics tools. Biotechnol. Lett. 2020, 42, 403-418. [CrossRef] [PubMed]

64. Chen, Y.F.; Lin, C.W.; Tsao, Y.P.; Chen, S.L. Cytotoxic-T-lymphocyte human papillomavirus type 16 E5 peptide with CpGoligodeoxynucleotide can eliminate tumor growth in C57BL/6 mice. J. Virol. 2004, 78, 1333-1343. [CrossRef] [PubMed]

65. Cordeiro, M.N.; Paolini, F.; Massa, S.; Curzio, G.; Illiano, E.; Silva, A.J.D.; Franconi, R.; Bissa, M.; Cde, G.M.; de Freitas, A.C.; et al. Anti-tumor effects of genetic vaccines against HPV major oncogenes. Hum. Vaccines Immunother. 2015, 11, 45-52. [CrossRef] [PubMed]

66. He, J.; Yang, Y.; Chen, Z.; Liu, Y.; Bao, S.; Zhao, Y.; Ding, X. Identification of variants and therapeutic epitopes in HPV-33/HPV-58 E6 and E7 in Southwest China. Virol. J. 2019, 16, 72. [CrossRef] [PubMed]

67. Kumar, A.; Yadav, I.S.; Hussain, S.; Das, B.C.; Bharadwaj, M. Identification of immunotherapeutic epitope of E5 protein of human papillomavirus-16: An in silico approach. Biologicals 2015, 43, 344-348. [CrossRef] [PubMed]

68. Liao, S.J.; Deng, D.R.; Zeng, D.; Zhang, L.; Hu, X.J.; Zhang, W.N.; Li, L.; Jiang, X.F.; Wang, C.Y.; Zhou, J.F.; et al. HPV16 E5 peptide vaccine in treatment of cervical cancer in vitro and in vivo. J. Huazhong Univ. Sci. Technol. Med. Sci. 2013, 33, 735-742. [CrossRef]

69. Liu, D.W.; Tsao, Y.P.; Hsieh, C.H.; Hsieh, J.T.; Kung, J.T.; Chiang, C.L.; Huang, S.J.; Chen, S.L. Induction of CD8 T cells by vaccination with recombinant adenovirus expressing human papillomavirus type 16 E5 gene reduces tumor growth. J. Virol. 2000, 74, 9083-9089. [CrossRef]

70. Liu, D.W.; Yang, Y.C.; Lin, H.F.; Lin, M.F.; Cheng, Y.W.; Chu, C.C.; Tsao, Y.P.; Chen, S.L. Cytotoxic T-lymphocyte responses to human papillomavirus type 16 E5 and E7 proteins and HLA-A*0201-restricted T-cell peptides in cervical cancer patients. J. Virol. 2007, 81, 2869-2879. [CrossRef]

71. Robinson, J.; Barker, D.J.; Georgiou, X.; Cooper, M.A.; Flicek, P.; Marsh, S.G.E. IPD-IMGT/HLA Database. Nucleic Acids Res. 2020, 48, D948-D955.

72. Dos Santos Francisco, R.; Buhler, S.; Nunes, J.M.; Bitarello, B.D.; Franca, G.S.; Meyer, D.; Sanchez-Mazas, A. HLA supertype variation across populations: New insights into the role of natural selection in the evolution of HLA-A and HLA-B polymorphisms. Immunogenetics 2015, 67, 651-663. [CrossRef]

73. Chowdhury, I.H.; Lokugamage, N.; Garg, N.J. Experimental Nanovaccine Offers Protection Against Repeat Exposures to Trypanosoma cruzi Through Activation of Polyfunctional T Cell Response. Front. Immunol. 2020, 11, 595039. [CrossRef] [PubMed]

74. Suschak, J.J.; Dupuy, L.C.; Shoemaker, C.J.; Six, C.; Kwilas, S.A.; Spik, K.W.; Williams, J.A.; Schmaljohn, C.S. Nanoplasmid Vectors Co-expressing Innate Immune Agonists Enhance DNA Vaccines for Venezuelan Equine Encephalitis Virus and Ebola Virus. Mol. Ther. Methods Clin. Dev. 2020, 17, 810-821. [CrossRef]

75. Peng, S.; Ferrall, L.; Gaillard, S.; Wang, C.; Chi, W.Y.; Huang, C.H.; Roden, R.B.S.; Wu, T.C.; Chang, Y.N.; Hung, C.F. Development of DNA Vaccine Targeting E6 and E7 Proteins of Human Papillomavirus 16 (HPV16) and HPV18 for Immunotherapy in Combination with Recombinant Vaccinia Boost and PD-1 Antibody. mBio 2021, 12, e03224-20. [CrossRef] [PubMed]

76. Ahrends, T.; Spanjaard, A.; Pilzecker, B.; Babala, N.; Bovens, A.; Xiao, Y.; Jacobs, H.; Borst, J. CD4 ${ }^{+}$T Cell Help Confers a Cytotoxic T Cell Effector Program Including Coinhibitory Receptor Downregulation and Increased Tissue Invasiveness. Immunity 2017, 47, 848-861.e5. [CrossRef] [PubMed]

77. Hobernik, D.; Bros, M. DNA Vaccines-How Far From Clinical Use? Int. J. Mol. Sci. 2018, 19, 3605. [CrossRef] [PubMed] 
78. Ahrends, T.; Babala, N.; Xiao, Y.; Yagita, H.; van Eenennaam, H.; Borst, J. CD27 Agonism Plus PD-1 Blockade Recapitulates CD4 ${ }^{+}$ T-cell Help in Therapeutic Anticancer Vaccination. Cancer Res. 2016, 76, 2921-2931. [CrossRef]

79. Gutierrez, C.M.C.; Tinoco, A.; Navarro, T.; Contreras, M.L.; Cortes, R.R.; Calzado, P.; Reyes, L.; Posternak, R.; Morosoli, G.; Verde, M.L.; et al. Therapeutic vaccination with MVA E2 can eliminate precancerous lesions (CIN 1, CIN 2, and CIN 3) associated with infection by oncogenic human papillomavirus. Hum. Gene Ther. 2004, 15, 421-431. [CrossRef] [PubMed]

80. Bagarazzi, M.L.; Yan, J.; Morrow, M.P.; Shen, X.; Parker, R.L.; Lee, J.C.; Giffear, M.; Pankhong, P.; Khan, A.S.; Broderick, K.E.; et al. Immunotherapy against HPV16/18 generates potent $\mathrm{T}_{\mathrm{H}} 1$ and cytotoxic cellular immune responses. Sci. Transl. Med. 2012, 4, 155ra138. [CrossRef]

81. Kim, T.J.; Jin, H.T.; Hur, S.Y.; Yang, H.G.; Seo, Y.B.; Hong, S.R.; Lee, C.W.; Kim, S.; Woo, J.W.; Park, K.S.; et al. Clearance of persistent HPV infection and cervical lesion by therapeutic DNA vaccine in CIN3 patients. Nat. Commun. 2014, 5, 5317. [CrossRef]

82. ClinicalTrials.gov. Vaccine Therapy with or without Imiquimod in Treating Patients with Grade 3 Cervical Intraepithelial Neoplasia. Available online: https:/ / clinicaltrials.gov/ct2/show / NCT00788164 (accessed on 28 October 2021).

83. Rosales, R.; Lopez-Contreras, M.; Rosales, C.; Magallanes-Molina, J.R.; Gonzalez-Vergara, R.; Arroyo-Cazarez, J.M.; RicardezArenas, A.; Del Follo-Valencia, A.; Padilla-Arriaga, S.; Guerrero, M.V.; et al. Regression of human papillomavirus intraepithelial lesions is induced by MVA E2 therapeutic vaccine. Hum. Gene Ther. 2014, 25, 1035-1049. [CrossRef]

84. Inovio Pharmaceutical Inc. INOVIO Announces Positive Results from REVEAL 1, a Phase 3 Pivotal Trial Evaluating VGX-3100, Its DNAbased HPV Immunotherapy for the Treatment of High-Grade Precancerous Cervical Dysplasia Caused by HPV-16 and/or HPV-18. 2021, pp. 1-6. Available online: https://www.prnewswire.com/news-releases/inovio-announces-positiveresults-from-reveal-1-a-phase-3-pivotal-trial-evaluating-vgx-3100-its-dna-based-hpv-immunotherapy-for-the-treatment-ofhigh-grade-precancerous-cervical-dysplasia-caused-by-hpv-16-andor-hpv-18-301237793.html (accessed on 21 January 2022).

85. Choi, Y.J.; Hur, S.Y.; Kim, T.J.; Hong, S.R.; Lee, J.K.; Cho, C.H.; Park, K.S.; Woo, J.W.; Sung, Y.C.; Suh, Y.S.; et al. A Phase II, Prospective, Randomized, Multicenter, Open-Label Study of GX-188E, an HPV DNA Vaccine, in Patients with Cervical Intraepithelial Neoplasia 3. Clin. Cancer Res. 2020, 26, 1616-1623. [CrossRef] [PubMed]

86. Hallez, S.; Simon, P.; Maudoux, F.; Doyen, J.; Noel, J.C.; Beliard, A.; Capelle, X.; Buxant, F.; Fayt, I.; Lagrost, A.C.; et al. Phase I/II trial of immunogenicity of a human papillomavirus (HPV) type $16 \mathrm{E} 7$ protein-based vaccine in women with oncogenic HPV-positive cervical intraepithelial neoplasia. Cancer Immunol. Immunother. 2004, 53, 642-650. [CrossRef]

87. Bakker, N.A.M.; Rotman, J.; van Beurden, M.; Zijlmans, H.J.M.; van Ruiten, M.; Samuels, S.; Nuijen, B.; Beijnen, J.; De Visser, K.; Haanen, J.; et al. HPV-16 E6/E7 DNA tattoo vaccination using genetically optimized vaccines elicit clinical and immunological responses in patients with usual vulvar intraepithelial neoplasia (uVIN): A phase I/II clinical trial. J. Immunother. Cancer 2021, 9, e002547. [CrossRef] [PubMed]

88. Chandra, J.; Woo, W.P.; Finlayson, N.; Liu, H.Y.; McGrath, M.; Ladwa, R.; Brauer, M.; Xu, Y.; Hanson, S.; Panizza, B.; et al. A phase 1 , single centre, open label, escalating dose study to assess the safety, tolerability and immunogenicity of a therapeutic human papillomavirus (HPV) DNA vaccine (AMV002) for HPV-associated head and neck cancer (HNC). Cancer Immunol. Immunother. 2021, 70, 743-753. [CrossRef]

89. Kaufmann, A.M.; Stern, P.L.; Rankin, E.M.; Sommer, H.; Nuessler, V.; Schneider, A.; Adams, M.; Onon, T.S.; Bauknecht, T.; Wagner U.; et al. Safety and immunogenicity of TA-HPV, a recombinant vaccinia virus expressing modified human papillomavirus (HPV)-16 and HPV-18 E6 and E7 genes, in women with progressive cervical cancer. Clin. Cancer Res. 2002, 8, 3676-3685. [PubMed]

90. Yang, A.; Peng, S.; Farmer, E.; Zeng, Q.; Cheng, M.A.; Pang, X.; Wu, T.C.; Hung, C.F. Enhancing antitumor immunogenicity of HPV16-E7 DNA vaccine by fusing DNA encoding E7-antigenic peptide to DNA encoding capsid protein L1 of Bovine papillomavirus. Cell Biosci. 2017, 7, 46. [CrossRef] [PubMed]

91. Ma, Y.; Yang, A.; Peng, S.; Qiu, J.; Farmer, E.; Hung, C.F.; Wu, T.C. Characterization of HPV18 E6-specific T cell responses and establishment of HPV18 E6-expressing tumor model. Vaccine 2017, 35, 3850-3858. [CrossRef]

92. De Oliveira, L.M.; Morale, M.G.; Chaves, A.A.; Cavalher, A.M.; Lopes, A.S.; Mde, O.D.; Schanoski, A.S.; de Melo, R.L.; Ferreira, L.C.; de Oliveira, M.L.; et al. Design, Immune Responses and Anti-Tumor Potential of an HPV16 E6E7 Multi-Epitope Vaccine. PLoS ONE 2015, 10, e0138686. [CrossRef] [PubMed]

93. Rosales, C.; Graham, V.V.; Rosas, G.A.; Merchant, H.; Rosales, R. A recombinant vaccinia virus containing the papilloma E2 protein promotes tumor regression by stimulating macrophage antibody-dependent cytotoxicity. Cancer Immunol. Immunother. 2000, 49, 347-360. [CrossRef] [PubMed]

94. Graham, V.V.; Sutter, G.; Jose, M.V.; Garcia-Carranca, A.; Erfle, V.; Mendoza, N.M.; Merchant, H.; Rosales, R. Human tumor growth is inhibited by a vaccinia virus carrying the E2 gene of bovine papillomavirus. Cancer 2000, 88, 1650-1662. [CrossRef]

95. Garcia-Hernandez, E.; Gonzalez-Sanchez, J.L.; Andrade-Manzano, A.; Contreras, M.L.; Padilla, S.; Guzman, C.C.; Jimenez, R.; Reyes, L.; Morosoli, G.; Verde, M.L.; et al. Regression of papilloma high-grade lesions (CIN 2 and CIN 3) is stimulated by therapeutic vaccination with MVA E2 recombinant vaccine. Cancer Gene Ther. 2006, 13, 592-597. [CrossRef] [PubMed]

96. Lindeque, B.G. Management of cervical premalignant lesions. Best Pract. Res. Clin. Obstet. Gynaecol. 2005, 19, 545-561. [CrossRef] [PubMed]

97. Yan, J.; Harris, K.; Khan, A.S.; Draghia-Akli, R.; Sewell, D.; Weiner, D.B. Cellular immunity induced by a novel HPV18 DNA vaccine encoding an E6/E7 fusion consensus protein in mice and rhesus macaques. Vaccine 2008, 26, 5210-5215. [CrossRef] [PubMed] 
98. Yan, J.; Reichenbach, D.K.; Corbitt, N.; Hokey, D.A.; Ramanathan, M.P.; McKinney, K.A.; Weiner, D.B.; Sewell, D. Induction of antitumor immunity in vivo following delivery of a novel HPV-16 DNA vaccine encoding an E6/E7 fusion antigen. Vaccine 2009, 27, 431-440. [CrossRef] [PubMed]

99. Sardesai, N. Cervical cancer immunotherapy: Induction of HPV specific CTLs in human volunteers after VGX-3100 immunization. In ECI Digital Archive: Vaccine Technology IV; Engineering Conferences International (ECI): Albufeira, Portugal, 2012.

100. Trimble, C.L.; Morrow, M.P.; Kraynyak, K.A.; Shen, X.; Dallas, M.; Yan, J.; Edwards, L.; Parker, R.L.; Denny, L.; Giffear, M.; et al. Safety, efficacy, and immunogenicity of VGX-3100, a therapeutic synthetic DNA vaccine targeting human papillomavirus 16 and $18 \mathrm{E} 6$ and E7 proteins for cervical intraepithelial neoplasia 2/3: A randomised, double-blind, placebo-controlled phase $2 \mathrm{~b}$ trial. Lancet 2015, 386, 2078-2088. [CrossRef]

101. ClinicalTrials.gov. REVEAL 2 Trial (Evaluation of VGX-3100 and Electroporation for the Treatment of Cervical HSIL). Available online: https: / clinicaltrials.gov/ct2/show / NCT03721978 (accessed on 27 October 2021).

102. Inovio Pharmaceutical Inc. INOVIO's VGX-3100 Demonstrates Positive Phase 2 Efficacy in Treatment of Precancerous Anal Dysplasia Caused by HPV-16/18. 2020. Available online: https://ir.inovio.com/news-releases/news-releases-details/2020 /INOVIOs-VGX-3100-Demonstrates-Positive-Phase-2-Efficacy-In-Treatment-of-Precancerous-Anal-Dysplasia-Caused-byHPV-1618/default.aspx (accessed on 21 January 2022).

103. Inovio Pharmaceutical Inc. INOVIO's VGX-3100 Demonstrates Positive Phase 2 Efficacy In Treatment of Precancerous Vulvar Dysplasia Caused by HPV-16/18. 2021. Available online: https://ir.inovio.com/news-releases/news-releases-details/2021 /INOVIOs-VGX-3100-Demonstrates-Positive-Phase-2-Efficacy-In-Treatment-of-Precancerous-Vulvar-Dysplasia-Caused-byHPV-1618/default.aspx (accessed on 21 January 2022).

104. Konya, J.; Eklund, C.; Geijersstam, V.A.; Yuan, F.; Stuber, G.; Dillner, J. Identification of a cytotoxic T-lymphocyte epitope in the human papillomavirus type 16 E2 protein. J. Gen. Virol. 1997, 78, 2615-2620.

105. Widera, G.; Austin, M.; Rabussay, D.; Goldbeck, C.; Barnett, S.W.; Chen, M.; Leung, L.; Otten, G.R.; Thudium, K.; Selby, M.J.; et al. Increased DNA vaccine delivery and immunogenicity by electroporation in vivo. J. Immunol. 2000, 164, 4635-4640. [CrossRef]

106. Selby, M.; Goldbeck, C.; Pertile, T.; Walsh, R.; Ulmer, J. Enhancement of DNA vaccine potency by electroporation in vivo. J. Biotechnol. 2000, 83, 147-152. [CrossRef]

107. Otten, G.; Schaefer, M.; Doe, B.; Liu, H.; Srivastava, I.; zur Megede, J.; O’Hagan, D.; Donnelly, J.; Widera, G.; Rabussay, D.; et al. Enhancement of DNA vaccine potency in rhesus macaques by electroporation. Vaccine 2004, 22, 2489-2493. [CrossRef]

108. Luckay, A.; Sidhu, M.K.; Kjeken, R.; Megati, S.; Chong, S.Y.; Roopchand, V.; Garcia-Hand, D.; Abdullah, R.; Braun, R.; Montefiori, D.C.; et al. Effect of plasmid DNA vaccine design and in vivo electroporation on the resulting vaccine-specific immune responses in rhesus macaques. J. Virol. 2007, 81, 5257-5269. [CrossRef]

109. Sales, N.S.; Silva, J.R.; Aps, L.; Silva, M.O.; Porchia, B.; Ferreira, L.C.S.; Diniz, M.O. In vivo electroporation enhances vaccinemediated therapeutic control of human papilloma virus-associated tumors by the activation of multifunctional and effector memory CD8 ${ }^{+}$T cells. Vaccine 2017, 35, 7240-7249. [CrossRef]

110. Carroll, A. Utilizing selection biomarkers in clinical trials: Is this the future of drug development? Biomark. Med. 2016, 10,939-941. [CrossRef]

111. Wong, C.H.; Siah, K.W.; Lo, A.W. Estimation of clinical trial success rates and related parameters. Biostatistics 2019, 20, 273-286. [CrossRef]

112. Harper, D.M.; Nieminen, P.; Donders, G.; Einstein, M.H.; Garcia, F.; Huh, W.K.; Stoler, M.H.; Glavini, K.; Attley, G.; Limacher, J.M.; et al. The efficacy and safety of Tipapkinogen Sovacivec therapeutic HPV vaccine in cervical intraepithelial neoplasia grades 2 and 3: Randomized controlled phase II trial with 2.5 years of follow-up. Gynecol. Oncol. 2019, 153, 521-529. [CrossRef]

113. Hillemanns, P.; Petry, K.; Woelber, L.; Böhmer, G.; Stubsrud, E.; Skjørestad, I.; Schjetne, K.; Fredriksen, A.; Axelsen, M. Safety, efficacy and immunogenicity of VB10.16, a therapeutic DNA vaccine targeting human papillomavirus (HPV) 16 E6 and E7 proteins for high grade cervical intraepithelial neoplasia (CIN 2/3): 6-month data from an exploratory open-label phase I/2a trial. In Proceedings of the American Association for Cancer Research (AACR) Annual Meeting, Atlanta, GA, USA, 29 March-3 April 2019; Volume 79.

114. Hillemanns, P.; Baurain, J.-F.; Blecharz, P.; Lindemann, K.; Nicolaisen, B.; Schetne, K.; Fredriksen, A.; Torhaug, S. A multi-centre, open-label phase II trial of the combination of VB10.16 and atezolizumab in patients with advanced or recurrent, non-resectable HPV16 positive cervical cancer. Ann. Oncol. 2020, 31, S645-S646. [CrossRef]

115. Chandra, J.; Dutton, J.L.; Li, B.; Woo, W.P.; Xu, Y.; Tolley, L.K.; Yong, M.; Wells, J.W.; Graham, R.L.; Finlayson, N.; et al. DNA Vaccine Encoding HPV16 Oncogenes E6 and E7 Induces Potent Cell-mediated and Humoral Immunity Which Protects in Tumor Challenge and Drives E7-expressing Skin Graft Rejection. J. Immunother. 2017, 40, 62-70. [CrossRef]

116. Lorenz, F.K.; Wilde, S.; Voigt, K.; Kieback, E.; Mosetter, B.; Schendel, D.J.; Uckert, W. Codon optimization of the human papillomavirus $\mathrm{E} 7$ oncogene induces a $\mathrm{CD}^{+} \mathrm{T}$ cell response to a cryptic epitope not harbored by wild-type E7. PLoS ONE 2015, 10, e0121633. [CrossRef]

117. Yaguchi, T.; Kawakami, Y. Cancer-induced heterogeneous immunosuppressive tumor microenvironments and their personalized modulation. Int. Immunol. 2016, 28, 393-399. [CrossRef]

118. Luo, Y.L.; Xu, C.F.; Li, H.J.; Cao, Z.T.; Liu, J.; Wang, J.L.; Du, X.J.; Yang, X.Z.; Gu, Z.; Wang, J. Macrophage-Specific in vivo Gene Editing Using Cationic Lipid-Assisted Polymeric Nanoparticles. ACS Nano 2018, 12, 994-1005. [CrossRef] 
119. Pardi, N.; Hogan, M.J.; Porter, F.W.; Weissman, D. mRNA vaccines-A new era in vaccinology. Nat. Rev. Drug Discov. 2018, 17, 261-279. [CrossRef]

120. Pulendran, B.; Arunachalam, P.S.; O'Hagan, D.T. Emerging concepts in the science of vaccine adjuvants. Nat. Rev. Drug Discov. 2021, 20, 454-475. [CrossRef]

121. McKee, A.S.; Marrack, P. Old and new adjuvants. Curr. Opin. Immunol. 2017, 47, 44-51. [CrossRef] [PubMed]

122. Borst, J.; Ahrends, T.; Babala, N.; Melief, C.J.M.; Kastenmuller, W. CD4 ${ }^{+} \mathrm{T}$ cell help in cancer immunology and immunotherapy. Nat. Rev. Immunol. 2018, 18, 635-647. [CrossRef]

123. Fujii, S.; Shimizu, K.; Smith, C.; Bonifaz, L.; Steinman, R.M. Activation of natural killer T cells by alpha-galactosylceramide rapidly induces the full maturation of dendritic cells in vivo and thereby acts as an adjuvant for combined CD4 and CD8 T cell immunity to a coadministered protein. J. Exp. Med. 2003, 198, 267-279. [CrossRef]

124. Piersma, S.J. Immunosuppressive tumor microenvironment in cervical cancer patients. Cancer Microenviron. 2011, 4, 361-375. [CrossRef]

125. Hanoteau, A.; Newton, J.M.; Krupar, R.; Huang, C.; Liu, H.C.; Gaspero, A.; Gartrell, R.D.; Saenger, Y.M.; Hart, T.D.; Santegoets, S.J.; et al. Tumor microenvironment modulation enhances immunologic benefit of chemoradiotherapy. J. Immunother. Cancer 2019, 7, 10. [CrossRef]

126. Kamphorst, A.O.; Araki, K.; Ahmed, R. Beyond adjuvants: Immunomodulation strategies to enhance T cell immunity. Vaccine 2015, 33, B21-B28. [CrossRef]

127. Van der Burg, S.H.; Arens, R.; Ossendorp, F.; van Hall, T.; Melief, C.J. Vaccines for established cancer: Overcoming the challenges posed by immune evasion. Nat. Rev. Cancer 2016, 16, 219-233. [CrossRef]

128. Shibata, T.; Lieblong, B.J.; Sasagawa, T.; Nakagawa, M. The promise of combining cancer vaccine and checkpoint blockade for treating HPV-related cancer. Cancer Treat. Rev. 2019, 78, 8-16. [CrossRef]

129. Moeini, S.; Saeidi, M.; Fotouhi, F.; Mondanizadeh, M.; Shirian, S.; Mohebi, A.; Gorji, A.; Ghaemi, A. Synergistic effect of programmed cell death protein 1 blockade and secondary lymphoid tissue chemokine in the induction of anti-tumor immunity by a therapeutic cancer vaccine. Arch. Virol. 2017, 162, 333-346. [CrossRef]

130. Paijens, S.T.; Vledder, A.; de Bruyn, M.; Nijman, H.W. Tumor-infiltrating lymphocytes in the immunotherapy era. Cell. Mol. Immunol. 2021, 18, 842-859. [CrossRef] [PubMed]

131. Zhang, Y.; Zhang, Z. The history and advances in cancer immunotherapy: Understanding the characteristics of tumor-infiltrating immune cells and their therapeutic implications. Cell. Mol. Immunol. 2020, 17, 807-821. [CrossRef] [PubMed]

132. Foppen, M.H.G.; Donia, M.; Svane, I.M.; Haanen, J.B. Tumor-infiltrating lymphocytes for the treatment of metastatic cancer. Mol. Oncol. 2015, 9, 1918-1935. [CrossRef] [PubMed]

133. Cordeiro, M.N.; De Lima, R.C.P.; Paolini, F.; Melo, A.; Campos, A.P.F.; Venuti, A.; De Freitas, A.C. Current research into novel therapeutic vaccines against cervical cancer. Expert Rev. Anticancer Ther. 2018, 18, 365-376. [CrossRef]

134. Bourhis, J.; Le, M.G.; Barrois, M.; Gerbaulet, A.; Jeannel, D.; Duvillard, P.; Le Doussal, V.; Chassagne, D.; Riou, G. Prognostic value of c-myc proto-oncogene overexpression in early invasive carcinoma of the cervix. J. Clin. Oncol. 1990, 8, 1789-1796. [CrossRef]

135. De Boer, M.A.; Jordanova, E.S.; Kenter, G.G.; Peters, A.A.; Corver, W.E.; Trimbos, J.B.; Fleuren, G.J. High human papillomavirus oncogene mRNA expression and not viral DNA load is associated with poor prognosis in cervical cancer patients. Clin. Cancer Res. 2007, 13, 132-138. [CrossRef]

136. Ward, M.J.; Thirdborough, S.M.; Mellows, T.; Riley, C.; Harris, S.; Suchak, K.; Webb, A.; Hampton, C.; Patel, N.N.; Randall, C.J.; et al. Tumour-infiltrating lymphocytes predict for outcome in HPV-positive oropharyngeal cancer. Br. J. Cancer 2014, 110, 489-500. [CrossRef]

137. Lin, R.J.; Lubpairee, T.; Liu, K.Y.; Anderson, D.W.; Durham, S.; Poh, C.F. Cyclin D1 overexpression is associated with poor prognosis in oropharyngeal cancer. J. Otolaryngol. Head Neck Surg. 2013, 42, 23. [CrossRef]

138. Yang, L.; Bai, H.S.; Deng, Y.; Fan, L. High MALAT1 expression predicts a poor prognosis of cervical cancer and promotes cancer cell growth and invasion. Eur. Rev. Med. Pharmacol. Sci. 2015, 19, 3187-3193.

139. Le, T.T.; Cramer, J.P.; Chen, R.; Mayhew, S. Evolution of the COVID-19 vaccine development landscape. Nat. Rev. Drug Discov. 2020, 19, 667-668. [CrossRef]

140. Polack, F.P.; Thomas, S.J.; Kitchin, N.; Absalon, J.; Gurtman, A.; Lockhart, S.; Perez, J.L.; Marc, G.P.; Moreira, E.D.; Zerbini, C.; et al. Safety and Efficacy of the BNT162b2 mRNA COVID-19 Vaccine. N. Engl. J. Med. 2020, 383, 2603-2615. [CrossRef] [PubMed]

141. Barda, N.; Dagan, N.; Ben-Shlomo, Y.; Kepten, E.; Waxman, J.; Ohana, R.; Hernan, M.A.; Lipsitch, M.; Kohane, I.; Netzer, D.; et al. Safety of the BNT162b2 mRNA COVID-19 Vaccine in a Nationwide Setting. N. Engl. J. Med. 2021, 385, 1078-1090. [CrossRef] [PubMed]

142. Verbeke, R.; Lentacker, I.; De Smedt, S.C.; Dewitte, H. The dawn of mRNA vaccines: The COVID-19 case. J. Control. Release 2021, 333, 511-520. [CrossRef] [PubMed]

143. Dagan, N.; Barda, N.; Kepten, E.; Miron, O.; Perchik, S.; Katz, M.A.; Hernan, M.A.; Lipsitch, M.; Reis, B.; Balicer, R.D. BNT162b2 mRNA COVID-19 Vaccine in a Nationwide Mass Vaccination Setting. N. Engl. J. Med. 2021, 384, 1412-1423. [CrossRef] [PubMed]

144. Klein, N.P.; Lewis, N.; Goddard, K.; Fireman, B.; Zerbo, O.; Hanson, K.E.; Donahue, J.G.; Kharbanda, E.O.; Naleway, A.; Nelson, J.C.; et al. Surveillance for Adverse Events After COVID-19 mRNA Vaccination. JAMA 2021, 326, 1390-1399. [CrossRef] [PubMed] 
145. Rosenblum, H.G.; Hadler, S.C.; Moulia, D.; Shimabukuro, T.T.; Su, J.R.; Tepper, N.K.; Ess, K.C.; Woo, E.J.; Mba-Jonas, A.; Alimchandani, M.; et al. Use of COVID-19 Vaccines After Reports of Adverse Events Among Adult Recipients of Janssen (Johnson \& Johnson) and mRNA COVID-19 Vaccines (Pfizer-BioNTech and Moderna): Update from the Advisory Committee on Immunization Practices-United States, July 2021. MMWR Morb. Mortal. Wkly. Rep. 2021, 70, 1094-1099.

146. Hopkins, J. FDA Authorizes Pfizer Vaccine for Young Children. Wall Str. J. 2021. Available online: https://www.msn.com/enus/health/medical/fda-authorizes-pfizer-vaccine-for-young-children/ar-AAQ6F2u?li=BBnb7Kz (accessed on 21 January 2022).

147. Khurana, A.; Allawadhi, P.; Khurana, I.; Allwadhi, S.; Weiskirchen, R.; Banothu, A.K.; Chhabra, D.; Joshi, K.; Bharani, K.K. Role of nanotechnology behind the success of mRNA vaccines for COVID-19. Nano Today 2021, 38, 101142. [CrossRef]

148. Pilkington, E.H.; Suys, E.J.A.; Trevaskis, N.L.; Wheatley, A.K.; Zukancic, D.; Algarni, A.; Al-Wassiti, H.; Davis, T.P.; Pouton, C.W.; Kent, S.J.; et al. From influenza to COVID-19: Lipid nanoparticle mRNA vaccines at the frontiers of infectious diseases. Acta Biomater. 2021, 131, 16-40. [CrossRef] 